\title{
Nutritional Composition of Detanninated and Fresh Pomegranate Peel Powder
}

\author{
S. C. Kushwaha ${ }^{1}$, M. B. Bera ${ }^{2}$ and Pradyuman Kumar $^{2}$ \\ ${ }^{1}$ Department of Food Engineering, NIFTEM, Kundli 131028 (Haryana) India \\ ${ }^{2}$ Department of Food Engineering \& Technology, \\ Sant Longowal Institute of Engineering and Technology, Longowal 148106 (Punjab) India.
}

\begin{abstract}
Pomegranate (Punica granatum) peel is a nutritive, antioxidant rich byproduct, easily available after production of pomegranate juice and ready to eat arils. The present study is undertaken to know the nutritional importance of fresh and detanninated pomegranate peel powder. Fresh pomegranate peel collected after juice extraction from Bhagwa variety of pomegranate. Fresh peels were crushed fine through grinder and passed through $2 \mathrm{~mm}$ sieve to collect homogeneous and uniform sized pomegranate peel. The crushed peels were divided in to two equal parts in which one part used for detannination and other part used as fresh pomegranate peel. One part of fresh pomegranate peel percolated in equal amount of water for 12 hour. The whole material squeezed through a muslin cloth and find out the detanninated solid peel portion. The fresh and detanninated pomegranate peel were dried in hot air oven and crushed it to get fine powder. Both fresh and detanninated pomegranate peel powder were evaluated for its nutritional value (eg. ash, ether extract, crude protein, crude fiber, neutral detergent fiber, acid detergent fiber, lignin, nitrogen free extract, metabolized energy, vitamins and minerals) including total tannin content as tannic acid. The fresh pomegranate peel powder showed good nutritional composition with high tannin content but detanninated peel powder showed double benefit i.e. separated hydrolysable tannin/ellagitannin and detanninated pomegranate peel powder containing good amount of nutritional components with appropriate amount of tannin which can be recommended as novel cattle feed supplement.
\end{abstract}

Keywords: Pomegranate, peel powder, detannination, nutritional value, cattle feed

\section{Introduction}

India is the largest producer of pomegranate (Punica granatum) next only to Iran. Pomegranate fruit is high in natural antioxidants and are known to fight against cancer, infections and other diseases in humans. Pomegranate peels are being discarded after juice production and ready to eat arils. Pomegranate peel is nutritive rich by product which are abundant due to no more use.

Pomegranate peel attracts attention due to its apparent wound healing properties (Chidambara et al., 2004), immune modultory activity (Gracious et al., 2001), and antibacterial activity (Navarro et al., 1996) antiatherosclerotic and antioxidative capacities (Tzulker et al., 2007). Antioxidative activity has often been associated with a decreased risk of various diseases (Whitley et al., 2003).

The cultivar per se (genotype) behaved as the most influencing factor conditioning pomegranate sugar, organic acid profiles, antioxidant activity and total phenolics. The genotype factor should be considered as the most influencing factor in future breeding programmes to enhance the synthesis of beneficial bioactive compounds (Pilar Legua et al., 2012).

Pomegranate peel is rich source of ellagitannin (antioxidant) and thus may serve in the prevention of cattle diseases and improvement of beef products making it an attractive component in cattle feed. Recent studies also have shown that boosting antioxidant levels in the diet of cattle may help to improve their health. The peel packs some of the weight boosting and health enhancing effects of antibiotics and hormones without the detrimental effects and it may yield meat with higher level of beneficial antioxidants (Shabtay et al., 2008). Pomegranate Ellagitannin have been identified as the active antioxidant compound and anticancer activities responsible for protecting low density lipoprotein, cholesterol from oxidation in vivo a key step in the pathogenesis of atherosclerosis. Pomegranate peel and its extracts are also being investigated for their potential uses as food biopreservatives, formulation of products in nutraceutical industry and cattle feed (N. Seeram et al., 2005).

A positive correlation between oxidative stress and illness is widely documented in cattles (Chirase et al, 2004; Miller et al., 1993). Recent studies have demonstrated higher antioxidant capacity of the peel as compared with the aril juice (Tzulker et al., 2007 and Li et al., 2006). This antioxidant capacity has been mainly atributed to the water soluble polyphenols, anthocyanins and hydrolysable tannins (Tzulker et al., 2007; Gil et al., 2000). The potent antioxidant capacity of pomegranate peel powder or it's extract against lipid peroxidation may be the central link for the antiatherogenic effects of pomegranate peel powder or it's extract on lipoproteins 
(Labib and Hossin, 2009). In the last few years the identification and development of phenolic compounds or extracts from different plants has become a major area of health and medical related research (Dai and Mumper, 2010).

The present study is undertaken to know the nutritional importance and suitability of detanninated pomegranate peel, a byproduct of pomegranate juice industry, as a cattle feed supplement.

\subsection{Preparation of Pomegranate Peel Sample:}

\section{Materials And Methods}

Fresh pomegranate fruits of "Bhagwa" variety were procured from Okhla Mandi, New Delhi. Fruits were peeled manually to separate peel and aril and obtained $31.1 \%$ of peel and pith portion. Peels were crushed in food grinder to reduce it to coarse size peel. The prepared peel devided in to two equal parts and one part was percolated in distilled water $(1: 1 \mathrm{w} / \mathrm{v})$ and kept at ambient condition for $12 \mathrm{~h}$ then whole material squeezed and filtered through muslin cloth and collected filtrate in a glass beaker which was used for the extraction of ellagitannin and solid residue left over muslin cloth were poured and spread in a glass petri dish. This detanninated pomegranate peel and above half portion of fresh pomegranate peel were placed in a hot air oven at $60{ }^{\circ} \mathrm{C}$ for $18 \mathrm{~h}$ to obtain dried material. The dried materials were crushed by food grinder in to powder form up to completely passed through $0.5 \mathrm{~mm}$ size sieve. Both detanninated and fresh pomegranate peel powder transferred in zip lock polyethylene bags separately for its physical and chemical analysis.

2.2 Physical Analysis: The detanninated and fresh peel powder were analyzed for sensory evaluation with respect to colour, odour and appearance.

2.3 Chemical Analysis: Fresh and detanninated pomrgranate peel powder were analyzed for the dry matter (DM) content by AOAC method 934.01, ash by AOAC method 942.05, ether extract (EE) by AOAC method 920.39, crude protein (CP) by AOAC method 984.13, crude fiber (CF) by AOAC method 978.10, neutral detergent fiber (NDF) by AOAC method 2002.04, acid detergent fiber (ADF) and lignin by using AOAC method 973.18. Nitrogen free extract (NFE) was calculated by using following equation (Le Houerou: 1980):

$$
\mathrm{NFE}(\% \mathrm{DM})=100-(\mathrm{CP}+\mathrm{CF}+\mathrm{EE}+\mathrm{Ash})
$$

Metabolized energy (ME) was calculated by using following equation (Garret, 1980)

$$
\mathrm{ME}(\mathrm{Mcal} / \mathrm{Kg} \mathrm{DM})=0.82 \mathrm{DE}
$$

Where DE stands for digestible energy which can be further calculated by using following equation (NRC, 1984):

$\mathrm{DE}(\mathrm{Mcal} / \mathrm{Kg} \mathrm{DM})=0.0504 \mathrm{CP}(\%)+0.077 \mathrm{EE}(\%)+0.02 \mathrm{CF}(\%)+0.000377 \mathrm{NFE}^{2}(\%)+0.011 \mathrm{NFE}(\%)-$ 0.152 (iii)

Total polyphenol content was determined in dried peel powder by using Folin-Ciocalteu reagent and calibrated against tannic acid (AOAC method 952.03). Vitamin A content was determined by spectrophotometric method (IS: 5886 -1970 reaffirmed: 2005). Minerals were determined by ashing of dried peel powder and solubilized to ash in dilute $\mathrm{HCl}+\mathrm{HNO}_{3}$ and analyzed for sodium (Na), potassium (K) by using flame photometer. Calcium (Ca) was determined by dry ash method described in AOAC method 927.02. Phosphorus (P) was analyzed by spectrophotometric method described in AOAC method 965.17. Magnesium $(\mathrm{Mg})$, iron $(\mathrm{Fe})$, copper $(\mathrm{Cu})$, zinc ( $\mathrm{Zn})$ and selenium (Se) were analyzed by atomic absorption spectrophotometer (AAS), model No. AANALYST200 of Perkin Elmer by using AOAC method.

All above experiment carried out in triplicate from same variety of pomegranate peel and results were compiled and reported the respective average value and standard deviation of each parameter.

\section{Results And Discussion}

The observation of detanninated and fresh pomegranate peel powder is represented in Table 1, which showed that fresh peel powder is darker in colour than detanninated powder and having pleasant odour. Table 2 showed the chemical composition (average value and standard deviation of three replicates) of both fresh and detanninated pomegranate peel powder.

\subsection{Table-1: Physical observation of detanninated and fresh pomegranate peel powder:}

\begin{tabular}{|c|c|c|}
\hline Parameters & Detanninated peel powder & Fresh Peel Powder \\
\hline Colour & Light brown colour & Dark Brown colour \\
\hline Odour & Characteristic with pleasant odour & Characteristic with tannin odour \\
\hline Appearance & Light brown coloured granular powder & Dark brown coloured granular powder \\
\hline
\end{tabular}


Nutritional Composition of Detanninated and Fresh Pomegranate Peel Powder

\subsection{Table-2: Chemical composition of fresh and detanninated peel powder}

\begin{tabular}{|l|c|c|}
\hline Components & Detanninated peel powder & Fresh peel powder \\
\hline Dry matter $(\mathrm{DM}) \% \mathrm{w} / \mathrm{w}$ & $17.63 \pm 0.62$ & $30.57 \pm 0.25$ \\
\hline Ash (inorganic matter) \%w/w & $3.29 \pm 0.69$ & $2.4 \pm 0.15$ \\
\hline Ether extract $(\mathrm{EE})(\mathrm{crude}$ fat) \%w/w & $1.43 \pm 0.22$ & $3.95 \pm 0.06$ \\
\hline Crude protein(CP) \% w/w & $6.43 \pm 0.37$ & $12.61 \pm 0.23$ \\
\hline Crude fiber $(\mathrm{CF}) \% \mathrm{w} / \mathrm{w}$ & $24.36 \pm 0.41$ & $17.83 \pm 0.15$ \\
\hline Neutral detergent fiber $(\mathrm{NDF}) \% \mathrm{w} / \mathrm{w}$ & $28.54 \pm 0.23$ & $14.55 \pm 0.07$ \\
\hline Acid Detergent fiber $(\mathrm{ADF}) \% \mathrm{w} / \mathrm{w}$ & $26.11 \pm 0.15$ & $4.29 \pm 0.41$ \\
\hline Lignin $\% \mathrm{w} / \mathrm{w}$ & $7.59 \pm 0.25$ & $75.54 \pm 0.32$ \\
\hline Nitrogen free extract(NFE) \%w/w & $64.49 \pm 0.96$ & $40.53 \pm 0.26$ \\
\hline Total polyphenol content $(\mathrm{mg} / \mathrm{gm})$ & $1.11 \pm 0.01$ & $14.06 \pm 0.08$ \\
\hline Vitamin $\mathrm{A}(\mu \mathrm{g} / \mathrm{gm})$ & $11.04 \pm 0.17$ & $763.66 \pm 0.73$ \\
\hline Sodium $(\mathrm{mg} / \mathrm{kg})$ & $362.74 \pm 0.96$ & $16237.41 \pm 0.96$ \\
\hline Potassium $(\mathrm{mg} / \mathrm{kg})$ & $6679.50 \pm 0.95$ & $645.70 \pm 0.88$ \\
\hline Calcium $(\mathrm{mg} / \mathrm{kg})$ & $728.23 \pm 0.89$ & $1644.47 \pm 0.86$ \\
\hline Magnesium $(\mathrm{mg} / \mathrm{kg})$ & $524.80 \pm 0.43$ & $33.96 \pm 0.75$ \\
\hline Phosphorus $(\mathrm{mg} / \mathrm{kg})$ & $57.01 \pm 0.74$ & $22.6 \pm 0.75$ \\
\hline Iron $(\mu \mathrm{g} / \mathrm{gm})$ & $18.33 \pm 0.40$ & $6.2 \pm 0.4$ \\
\hline Copper $(\mu \mathrm{g} / \mathrm{gm})$ & $4.67 \pm 0.15$ & $8.03 \pm 0.67$ \\
\hline Zinc $(\mu \mathrm{g} / \mathrm{gm})$ & $9.63 \pm 0.31$ & Not Detected \\
\hline Selenium $(\mu \mathrm{g} / \mathrm{gm})$ & Not Detected & \\
\hline
\end{tabular}

The above comparative results of fresh and detanninated pomegranate peel powder showed some variable trends in their respective test values. The detanninated pomegranate peel powder (DPPP) test showed dry matter (17.63\%), ash content $(3.29 \%)$, EE (1.43\%) values and fresh pomegranate peel Powder (FPPP) test showed dry matter $(30.57 \%)$, ash content $(5.49 \%)$ and EE $(2.43 \%)$. Detanninated pomegranate peel powder containing lower amount of DM, ash content and EE values than fresh pomegranate peel powder while the detanninated pomegranate peel powder contain significantly higher CP (6.43\%), CF (24.36\%), NDF (28.54\%), ADF (26.11\%) and lignin (7.59\%) than the fresh pomegranate dried peel's values of CP (3.95\%), CF (12.61\%), NDF (17.83\%), $\mathrm{ADF}(14.55 \%)$ and lignin (4.29\%).

Higher test values in DPPP than FPPP indicates retention and accumulation of above components during detannination process but in case of lower test values in DPPP than FPPP indicated that losses of above components during detannination process. The calculated metabolized energy in DPPP (2.50 Mcal $/ \mathrm{Kg} \mathrm{DM})$ and in FPPP $(2.84 \mathrm{Mcal} / \mathrm{Kg} \mathrm{DM})$ is almost equal which indicates there is no more difference between FPPP and DPPP in terms of producing the energy inside the body. Tannin content obviously would be lower in the DPPP because it was intensionally detanninated to improve the odour, colour and appearance of pomegranate peel which had been differentiated by physical observation of colour, odour and appearance of detanninated and fresh pomegranate peel powder and found that better improvement in colour, odour and appearence of detanninated pomegranate peel powder i.e. free from tannin odour which makes it more acceptable than fresh pomegranate peel powder because FPPP have high tannin content (4.05\%) and high tannin odour which makes it unacceptable or unliking by cattle.

Tannins are considered to have both adverse and beneficial effects in ruminant's animal (Makkar et al., 2003). High concentration of tannin may reduce intake, digestibility of protein and carbohydrates, and animal performance through their negative effect on palatability and digestion (Reed, 1995). By preventing bloat and increasing the flow of non ammonia nitrogen and essential amino acid from the rumen (Min et al., 2003) low and moderate (20-45 mg/gm D.M.) concentration of condensed tannins in the diet improved production efficiency in ruminant, without increasing feed intake. This was manifested by increases in wool growth, weight gain, milk yield and ovulation rate (Aerts et al., 1999).

DPPP contain lower content of Vitamin A $(11.04 \mu \mathrm{g} / \mathrm{gm})$ and minerals like $\mathrm{Na}(362.74 \mathrm{mg} / \mathrm{kg}), \mathrm{K}$ $(6679.5 \mathrm{mg} / \mathrm{kg}), \mathrm{Mg}(524.80 \mathrm{mg} / \mathrm{kg}), \quad \mathrm{Fe}(18.33 \mu \mathrm{g} / \mathrm{gm})$ and $\mathrm{Cu}(4.67 \mu \mathrm{g} / \mathrm{gm})$ while in FPPP slightly higher values of Vitamin A $(14.06 \mu \mathrm{g} / \mathrm{gm})$ and minerals like $\mathrm{Na}(763.66 \mathrm{mg} / \mathrm{kg}), \mathrm{K}(16237.4 \mathrm{mg} / \mathrm{kg}), \mathrm{Mg}(1644.47$ $\mathrm{mg} / \mathrm{kg}), \mathrm{Fe}(22.6 \mu \mathrm{g} / \mathrm{gm})$ and $\mathrm{Cu}(6.2 \mu \mathrm{g} / \mathrm{gm})$ has been found i.e. justifiable due to loss of these minerals during detannination process, but opposite to this there is few minerals like Ca $(728.23 \mathrm{mg} / \mathrm{kg}), \mathrm{P}(57.01 \mathrm{mg} / \mathrm{kg})$ and $\mathrm{Zn}$ $(9.63 \mu \mathrm{g} / \mathrm{gm})$ content found slightly higher in DPPP than FPPP minerals content Ca $(645.70 \mathrm{mg} / \mathrm{kg}), \mathrm{P}(33.96$ $\mathrm{mg} / \mathrm{kg})$ and $\mathrm{Zn}(8.03 \mu \mathrm{g} / \mathrm{gm})$ which could be understand that these minerals have not lossed during detannination process and finally retained in concentrated amount in DPPP. The selenium was the only mineral which was not detected up to $1 \mu \mathrm{g} / \mathrm{gm}$ detection limit in both DPPP and FPPP.

The above test values of DPPP are further comparable with nutritional components (DM, ash content, EE, CP, ADF, NDF, CF, DE, Na, K, Ca, P, and Zn) (Table-3) of different feed stuffs of Barley straw, oat straw, corn bran, rye straw, soya bean straw, sunflower hull, wheat straw, pea straw. Detanninated pomegranate peel powder showed good amount of nutritional components than FPPP except few elements. 
3.4. Table 3: Typical composition of feeds for cattle and sheep (T.L. Stauton and S. Le Valley, 2006)

\begin{tabular}{|c|c|c|c|c|c|c|c|c|c|c|c|c|c|}
\hline \multirow{2}{*}{ Feed stuff } & \multicolumn{13}{|c|}{ Nutritional composition } \\
\hline & $\begin{array}{l}\text { DM } \\
(\%)\end{array}$ & $\begin{array}{l}\text { Ash } \\
(\%)\end{array}$ & $\begin{array}{l}\text { EE } \\
(\%)\end{array}$ & $\begin{array}{l}\text { CP } \\
(\%)\end{array}$ & $\begin{array}{l}\text { ADF } \\
(\%)\end{array}$ & $\begin{array}{l}\text { NDF } \\
(\%)\end{array}$ & $\begin{array}{l}\text { CF } \\
(\%)\end{array}$ & DE (\%) & $\begin{array}{l}\mathrm{Na} \\
(\%)\end{array}$ & $\begin{array}{l}\text { K } \\
(\%)\end{array}$ & $\begin{array}{l}\mathrm{Ca} \\
(\%)\end{array}$ & $\begin{array}{l}P \\
(\%)\end{array}$ & $\begin{array}{l}\mathrm{Zn} \\
\text { (ppm } \\
\text { ) }\end{array}$ \\
\hline $\begin{array}{l}\text { Barley } \\
\text { straw }\end{array}$ & 88 & 7 & 1.9 & 4 & 57 & 82 & 42 & 0.98 & - & 2.0 & 0.3 & 0.05 & 7 \\
\hline Oat straw & 90 & 8 & 2.3 & 4 & 46 & 70 & 41 & 1.0 & - & 2.2 & 0.10 & 0.10 & 6.0 \\
\hline Corn bran & 90 & 3 & 6.3 & 10 & - & 51 & 10 & 1.52 & - & 0.7 & 0.0 & 0.17 & - \\
\hline Rye straw & 89 & 6 & 1.5 & 4 & 55 & 71 & 44 & 0.88 & & 1.0 & 0.3 & 0.1 & - \\
\hline $\begin{array}{l}\text { Soya bean } \\
\text { straw }\end{array}$ & 88 & 6 & 1.4 & 5 & 54 & 70 & 44 & 0.84 & - & 0.6 & 1.6 & 0.06 & - \\
\hline $\begin{array}{l}\text { Sunflower } \\
\text { hull }\end{array}$ & 90 & 3 & 2.2 & 5 & 63 & - & 25 & 0.80 & - & - & - & 0.11 & - \\
\hline $\begin{array}{l}\text { Wheat } \\
\text { straw }\end{array}$ & 88 & 7.0 & 1.5 & 4 & 56 & 85 & 42 & 0.88 & - & 1.2 & 0.2 & 0.08 & 7 \\
\hline Pea straw & 89 & 7 & 1.3 & 7 & - & - & 45 & 1.00 & - & 1.10 & - & 0.11 & - \\
\hline
\end{tabular}

\section{Conclusion}

From above comparative results and discussion of fresh and detanninated pomegranate peel powder it can be concluded that pomegranate peel i.e. Fruit juice industrial waste can be further utilized by tannin extraction and rest other byproduct (i.e. solid peel residue) can be produced as cattle feed supplement loaded with beneficial nutritional component at very low cost. Although fresh peel powder also exhibit higher amount of nutritional component except few components but it was found that its higher tannin content reflects in its odour which makes it unpleasant and bitter due to which cattles may dislike it. Apart from this in detanninated peel there is two advantages first one is that gain of useful hydrolysable ellagitannin which can be further utilized in different Food, drugs and cosmetics as additives while other one is that gain of nutritious detanninated peel powder with improved odour which also contains a sufficient amount of tannin (i.e. $0.11 \%$ ) as in residual form. The detanninated and fresh pomegranate peel powder showed almost equal calculated metabolized energy value, which is a supportive remark to recommend and use of detanninated pomegranate peel powder as a novel cattle feed supplement.

\section{References}

[1]. Aerts, R. J.; Barry, T. N.; McNabb, W. C. Polyphenols and agriculture: Beneficial effects of proanthocyanidins in forages. Agric. Ecosyst. EnViron. 1999 ,75: 1-12

[2]. AOAC, Official method of analysis of AOAC international, (2006) 18t Ed., AOAC INETRNATIONAL, Gaitersburg, MD, USA.

[3]. Aviram, M.; Volkova, N.; Coleman, R.; Dreher, M.; Reddy, M. K.;Ferreira, D.; Rosenblat, M. Pomegranate phenolics from the peels,arils, and flowers are antiatherogenic: Studies in vivo in athero-sclerotic apolipoprotein E-deficient (E0) mice and in vitro in cultured macrophages and lipoproteins.J. Agric. Food Chem. 2008, 56: 1148-1157.

[4]. Chidambara, M. K.; Reddy, V. K.; Veigas, J. M.; Murthy, U. D. Study on wound healing activity of Punicagranatum peel. J. Med. Food 2004, 7:256-259.

[5]. Chirase, N. K.; Greene, L. W.; Purdy, C. W.; Loan, R. W. ;Auvermann, B. W.; Parker, D. B.; Walborg, E. F., Jr.; Stevenson,D. E.; $\mathrm{Xu}, \mathrm{Y}$;; Klaunig, J. E. Effect of transport stress on respiratory disease, serum antioxidant status, and serum concentrations of lipid peroxidation biomarkers in beef cattle. Am. J. Vet. Res. 2004, 65: 860-864

[6]. Dai, J. and Mumper, R.J. Plant Phenolics: Extraction, Analysis and their antioxidant and Anticancer Properties. Molecules 2010, 15: 7313-7352.

[7]. Garrett, W.N. Energy utilization of growing cattle as determined in seventy two comparative slaughter experiments. In L.E. Mount (ed): Energy Metabolism, EAAP Publ. No. 26, 1980, London.

[8]. Gil, M. I.; Tomas-Barberan, F. A.; Hess-Pierce, B.; Holcroft,D. M.; Kader, A. A. Antioxidant activity of pomegranate juice and its relationship with phenolic composition and processing. J. Agric. Food Chem. 2000, 48: 4581-4589.

[9]. Gorelik, S.; Lapidot, T.; Shaham, I.; Granit, R.; Ligumsky, M.;Kohen, R.; Kanner, J. Lipid peroxidation and coupled vitamin oxidation in simulated and human gastric fluid inhibited by dietary polyphenols: Health implications. J. Agric. Food Chem.2005, 53: 3397-3402.

[10]. Gracious, R. R.; Selvasubramanian, S.; Jayasundar, S. Immuno-modulatory activity of Punica granatum in rabbits s A preliminary study. J. Ethnopharmacol. 2001, 78: 85-87.

[11]. Hays, V. S.; Gill, D. R.; Smith, R. A.; Ball, R. L. The effect of vitamin E supplementation on performance of newly received stocker cattle. Oklahoma State University. Anim. Sci. Res. Rep. 1978, MP-199, 198-201.

[12]. Huxley, R. R.; Neil, H. A. W. The relationship between dietary flavonol intake and coronary heart disease mortality: A metaanalysis of prospective cohort studies. Eur. J. Clin. Nutr.2003, 57:904-908.

[13]. IS: 5886 -1970 reaffirmed: 2005 , Metod for estimation of carotenes and vitamin A(retinol) in food stuffs.

[14]. Labib, F. and Hossin, A. Effect of pomegranate (Punicagranatum) Peels and its Extract on Obese Hyperdholestrolemic Rats.; Pakistan Journal of Nutrition 2009, 8: 1251-1257.

[15]. Lavelle, C. L.; Hunt, M. C.; Kropf, D. H. Display life and internal cooked color of ground beef from vitamin E-supplemented steers. J. Food Sci.1995, 60, 1175-1179. 
[16]. Le houerou, H.N. 1980. Chemical composition and nutritive value of browse in Tropical West Africa. In Le Houerou (ed): Browse in Africa, ILCA, Addis Ababa: 261-289.

[17]. Li, Y.; Guo, C.; Yang, J.; Wei, J.; Xu, J.; Cheng, S. Evaluation of antioxidant properties of pomegranate peel extract in comparison with pomegranate pulp extract. Food Chem.2006, 96: 254-260.

[18]. Makkar, H. P. S. Effects and fate of tannins in ruminant animals, adaptation to tannins, and strategies to overcome detrimental effects of feeding tannin-rich feeds. Small Ruminant Res.2003, 49: 241-256

[19]. Miller, J. K.; Brzezinska-Slebodzinska, E.; Madsen, F. C. Oxidative stress, antioxidants, and animal function. J. Dairy Sci.1993, 76: 2812-2823.

[20]. Min, B. R.; Barry, T. N.; Attwood, G. T; McNabb, W. C. The effect of condensed tannins on the nutrition and health of ruminants fed fresh temperate forages: A review. Anim. Feed Sci.Technol. 2003, 106: 3-19.

[21]. N. Seeram, R. Lee, M. Hardy, D. Heber, "Rapid large scale purification of ellagitannins from pomegranate husk, a by-product of the commercial juice industry" Separation and Purification Technology (2005), 41: 49-55.

[22]. Navarro, V.; Villarreal, M. L.; Rojas, G.; Lozoya, X. Antimicrobial evaluation of some plants used in Mexican traditional medicinefor the treatment of infectious diseases. J. Ethnopharmacol. 1996, 53: 143-147.

[23]. NRC 1984. Nutrient requirements of domestic animals: nutrient requirement of beef cattle (6 ${ }^{\text {th }}$ Edn.). National Research Council No.5, Washington DC, Nat. Acad. Sci., 90 pp.

[24]. Pilar Legua, Pablo Melgarejo, Haddioui Abdelmajid, Juan Jose Martinez, Rafael Martinez, Hamid llham, Hanine Hafida and Francisca Hernandez,; Total Phenols and Antioxidant capacity in 10 Moroccan Pomegranate Varieties.; Journal of Food Science. 2012, Vol. 7, Nr 1, C115.

[25]. Reed, J.D. nutritional toxicology of tannins and related polyphenols in forage legumes. J. Anim. Sci. 1995, 73, 1516-1528.

[26]. Shabtay, A., Eitam, H., Tadmor, Y., Orlov, A., Meir, A., Weinberg, P., Weinberg, Z.G., Chen, Y., Brosh, A., Izhaki, I. and Kerem, Z. ().Nutritive and antioxidative potential of fresh and stored pomegranate industrial waste as novel beef cattle feed. J. Agric. Food Chem. 2008, 56(21):10063-10070.

[27]. T.L. Stauton and S. Le Valley, Feed composition for cattle and sheep., Colorado State University Cooperative Extension, (2/06) no. 1.615

[28]. Tzulker, R.; Glazer, I.; Bar-Ilan, I.; Holland, D.; Aviram, M.; Amir,R. Antioxidant activity, polyphenol content, and related compounds in different fruit juices and homogenates prepared from 29 different pomegranate accessions. J. Agric. Food Chem.2007, 55: 9559-9570.

[29]. Whitley, A. C.; Stoner, G. D.; Darby, M. V.; Walle, T. Intestinal epithelial cell accumulation of the cancer preventive polyphenol ellagic acids Extensive binding to protein and DNA. Biochem. Pharmacol. 2003, 66: 907-915. 